\title{
STRATEGI PENANGGULANGAN KEMISKINAN DI KOTA JAKARTA TIMUR
}

\author{
Strategy of Overcoming Poverty in East Jakarta Municipality
}

\author{
Sarjono1, Sri Hartoyo², Dedi Budiman Hakim $^{3}$
}

\begin{abstract}
1Staf Auditor Badan Pengawasan Keuangan dan Pembangunan RI. email :sarjono.jkm@gmail.com ${ }^{2}$ Guru Besar Ilmu Ekonomi. Fakultas Ekonomi dan Manajemen. IPB. email : shty@indo.net.id ${ }^{3}$ Staff Pengajar Departemen Ilmu Ekonomi. Fakultas Ekonomi dan Manajemen. IPB.email : dedihakim@gmail.com
\end{abstract}

\begin{abstract}
Poverty is one of a complex problem that remains unresolved in the state of Indonesia. The government of East Jakarta Municipallity has taken much effort to break the cycle of poverty, but the rate of poverty in East Jakarta City is still fluctuating. This study aimed to analyze the factors affecting the chances of poor household growt. Based on Logistic Regression Analysis demonstrated that gender and a number of household members positively have a significant effect on the chance of poor household development, while the number of productive members in household have a negative effect.
\end{abstract}

Keywords : Logistic Regression, Poverty

\section{ABSTRAK}

Kemiskinan merupakan salah satu masalah yang kompleks yang belum terpecahkan di Indonesia. Pemerintah Kota Jakarta Timur telah melakukan berbagai upaya untuk mengatasi masalah kemiskinan, namun angka kemiskinan di Kota Jakarta Timur masih fluktuatif. Tujuan dari penelitian ini adalah untuk menganalisis faktor-faktor yang menyebabkan terjadinya rumah tangga miskin. Hasil Analisis Regresi Logistik menunjukan bahwa gender dan besaran anggota rumah tangga berpengaruh positif dan signifikan terhadap kejadian rumah tangga miskin sedangkan proporsi anggota rumah tangga yang bekerja, berpengaruh negatif dan signifikan terhadap kejadian rumah tangga miskin.

Kata kunci: Kemiskinan, Regresi Logistik

\section{PENDAHULUAN}

Kemiskinan merupakan persoalan mendasar yang menjadi fokus dan perhatian utama Pemerintah Indonesia. Kemiskinan menyebabkan seseorang atau sekelompok orang tidak mampu memenuhi hak-hak dasarnya seperti tidak terpenuhinya kebutuhan pangan, kesehatan, pendidikan, pekerjaan, perumahan, air bersih, pertanahan, sumber daya alam dan lingkungan hidup (BPS, 2009). Indonesia sebagai bagian dari negara dunia ketiga, dalam proses pembangunan dan sejarahnya belum pernah bebas dari persoalan kemiskinan
(Kasim, 2006).

Program MDGs menargetkan bagi 191 negara anggota PBB di akhir tahun 2015 bisa mengurangi jumlah warga miskinnya menjadi setengah dari pada jumlah di tahun 2000 (Tambunan, 2016). Menurut Adianti (2005) kemiskinan di DKI Jakarta selama tahun 2000-2004 mengalami fluktuasi. Dua tahun setelah krisis ekonomi, pada tahun 2000 angka kemiskinan di DKI Jakarta masih tinggi yaitu 4,9 persen. Pada tahun 2001 turun menjadi 2,9 persen karena adanya program pengentasan kemiskinan. Namun naik kembali menjadi 3,42 persen (20022003) dan menurun menjadi 3,18 persen 
pada tahun 2004.

Seperti halnya masalah kemiskinan, Kota Jakarta Timur juga menghadapi masalah pengangguran (BPS Kota Jakarta Timur, 2015). Tingkat Pengangguran Terbuka (TPT) di Kota Jakarta Timur tahun 2015 (9,13 persen) lebih tinggi dari pada TPT Provinsi DKI (7,23 persen) dan TPT Nasional (6,18 persen). Beberapa indikator ekonomi makro dan kebijakan di Kota Jakarta Timur cukup menunjang bagi terciptanya kesejahteraan warga antara lain yaitu: (1) anggaran penanggulangan kemiskinan di Kota Jakarta Timur tahun 2012 sebesar 421 milyar rupiah dan meningkat menjadi 624 milyar rupiah pada tahun 2013 (2) PDRB per kapita atas dasar harga konstant pada tahun 2010, adalah 68,93 juta rupiah naik menjadi 87,65 juta rupiah pada tahun 2015, dan (3) IPM Kota Jakarta Timur mempunyai angka yang relatif tinggi dan trend positif (meningkat) setiap tahunnya. Dari 78,74 di tahun 2009 dan menjadi 80,40 di tahun 2014. Berdasarkan uraian di atas maka tujuan dari penelitian ini adalah untuk menganalisis faktor-faktor yang mempengaruhi terjadinya kemiskinan rumah tangga.

\section{METODE PENELITIAN}

\section{Metode Pengumpulan, Pengolahan dan Analisis Data}

Data yang digunakan adalah data skunder yang bersumber dari publikasi BPS Pusat, Bappenas, BPS Provinsi DKI, Bappeda Provinsi DKI, Kantor Perencanaan dan Pembangunan Kota (Kanppeko) Jakarta Timur dan BPS Kota Jakarta Timur. Pengumpulan data dilakukan dengan cara studi kepustakaan dan studi dokumen. Data skunder meliputi data cross section penduduk miskin dan rentan miskin hasil Susenas tahun 2013, data batas Garis Kebutuhan Hidup Cukup di Provinsi DKI Jakarta, data statistik kemiskinan di Provinsi DKI, laporan monitoring program-program penanggulangan kemiskinan di Kota Jakarta Timur serta data statistik kemiskinan di Kota Jakarta Timur.

Metode analisis data dalam penelitian ini adalah Analisis Regresi Logistik yaitu analisis yang digunakan untuk mengetahui faktor-faktor yang mempengaruhi terjadinya kemiskinan rumah tangga. Selanjutnya, model regresi logistik dalam penelitian ini adalah

$$
\begin{aligned}
\ln \left(\frac{P_{i}}{1-P_{i}}\right)= & \beta_{0}+\beta_{1} J K_{i}+\beta_{2} \text { Umur }_{i}+\beta_{3} \text { ARTKer }_{i}+\beta_{4} \text { ARTKer }_{i}+\beta_{5} \text { DStat }_{1 i}+\beta_{6} \text { DStat }_{2 i} \\
& +\beta_{7} \text { DPend }_{1 i}+\beta_{8} \text { DPend }_{2 i}+\varepsilon_{i}
\end{aligned}
$$

Keterangan:

$\mathrm{Pi} \quad$ : Probabilitas terjadinya rumah tangga miskin $(\mathrm{Y}=1)$

1-Pi : Probabilitas tidak terjadinya rumah tangga miskin $(\mathrm{Y}=0)$

$\mathrm{JKi} \quad$ : Variabel dummy jenis kelamin/gender kepala rumah tangga, dengan nilai 1 jika perempuan dan 0 jika selainnya (laki-laki)

Umuri : Umur kepala rumah tangga (tahun)

$\mathrm{ARTi}_{\mathrm{i}}$ : Besaran anggota rumah tangga (orang)

ARTKeri : Besaran anggota rumah tangga yang bekerja (orang)

DStat1i : Variabel dummy 1 status/jenis pekerjaan kepala rumah tangga, dengan nilai 1 jika buruh dan 0 jika selainnya

DStat2i : Variabel dummy 2 status/jenis pekerjaan kepala rumah tangga, dengan nilai 1 jika wirausaha dan 0 jika selainnya

DPend1i : Variabel dummy 1 pendidikan kepala rumah tangga, dengan nilai 1 jika maksimal SD dan 0 jika selainnya

DPend2i : Variabel dummy 2 pendidikan kepala rumah tangga, dengan nilai 1 jika maksimal SMP dan 0 jika selainnya

$\beta_{0} \quad$ : Konstanta

$\beta 1-\beta 8 \quad$ : Estimasi parameter

i : Responden

$\varepsilon \quad$ : Error 


\section{HASIL DAN PEMBAHASAN}

\section{Kondisi Perekonomian berdasarkan PDRB per kapita dan IPM}

Untuk memberikan gambaran kemakmuran suatu wilayah secara umum salah satunya dapat dilihat dari nilai PDRB per kapita. Nilai PDRB per kapita Jakarta Timur atas dasar harga konstan 2010 mengalami peningkatan setiap tahunnya. Sejak tahun 2010 sampai dengan tahun 2015, PDRB perkapita Kota Jakarta Timur naik sebesar 18,72 juta rupiah dari 68,93 juta rupiah menjadi 87,65 juta rupiah (terjadi pertumbuhan/tahun sebesar 3,74 juta rupiah).

Selain pertumbuhan ekonomi pengukuran keberhasilan pembangunan suatu wilayah dapat dilihat juga dari pengaruh pembangunan terhadap kualitas manusianya. Indikator yang yang dipakai untuk mengukur kualitas hidup manusia (masyarakat/penduduk) adalah IPM (Indeks Pembangunan Manusia). IPM menjelaskan bagaimana penduduk dapat mengakses hasil pembagunan dalam memperoleh pendapatan, kesehatan, pendidikan dan sebagainya. IPM dibentuk oleh tiga dimensi dasar yaitu kesehatan (angka harapaan hidup saat lahir), pendidikan (harapan lama sekolah dan rata-rata lama sekolah) dan standar hidup (pengeluaran per kapita disesuaikan). Nilai IPM Kota Jakarta Timur adalah yang tertinggi kedua setelah Kota Jakarta Selatan. IPM Kota Jakarta Timur pada kurun waktu antara tahun 2009-2014 menunjukkan peningkatan sebesar 1,66 poin dari 78,74 menjadi 80,40 (BPS Kota Jakarta Timur, 2015).

\section{Perkembangan Tingkat Kemiskinan}

Untuk melihat perkembangan tingkat kemiskinan di Kota Jakarta Timur dapat diketahui berdasarkan data survey yang dilakukan oleh Badan Pusat Statistik (BPS) yaitu Survei Sosial Ekonomi Nasional (Susenas).Susenas merupakan data makro yang dapat digunakan oleh pemerintah daerah untuk mengambil suatu kebijakan.

Berdasarkan data BPS Kota Jakarta Timur, persentase penduduk miskin di Jakarta Timur pada tahun 2005 hanya sebesar 2,85 persen dan meningkat signifikan pada tahun 2007 (tertinggi) sebesar 4,02 persen. Selanjutnya persentasenya kembali menurun pada tahun 2010 menjadi 3,40 persen atau sejumlah 91,6 ribu jiwa. Gambar 1 menjelaskan perkembangan tingkat kemiskinan di Kota Adminitrasi Jakarta Timur dibandingkan Tingkat kemiskinan pada Provinsi DKI antara tahun 20052013.

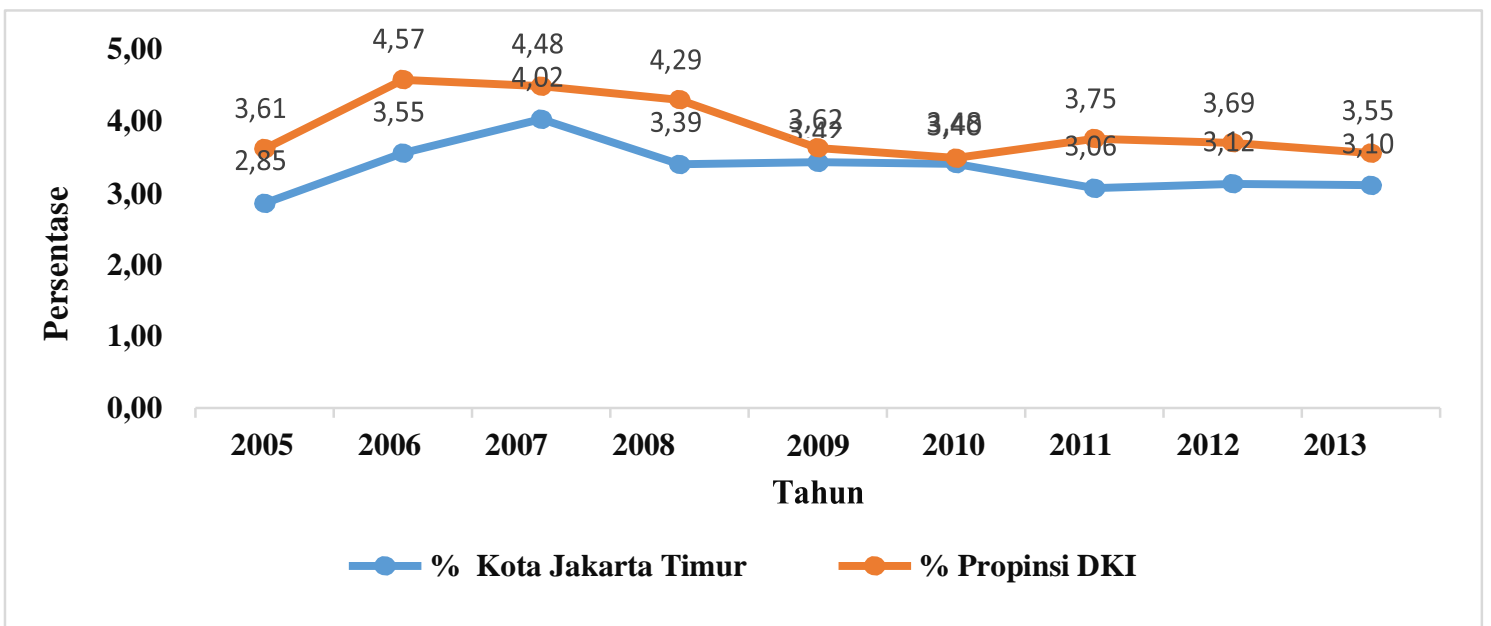

Gambar 1 Perbandingan persentase tingkat kemiskinan di Kota Jakarta Timur dan Provinsi DKI 

Beberapa faktor yang menyebabkan fluktuatifnya kemiskinan di Kota Jakarta Timur dapat dijelaskan dari beberapa hasil penelitian dengan topik kemiskinan: Adianti (2005) dan Aryanti (2011) dengan kesimpulan yang hampir sama yaitu ada variabel- variabel dalam rumah tangga yang menjadi faktor penyebab terjadinya kemiskinan rumah tangga yaitu perempuan (gender), besaran anggota rumah tangga dan proporsi anggota rumah tangga yang bekerja.

Selanjutnya Aryanti (2011), Tasrif et al. (2008) dan Bappenas (2015) menambahkan bahwa ada faktor-faktor lain yang menjadi penyebab terjadinya kemiskinan rumah tangga yaitu pendidikan kepala rumah tangga dan jenis/status pekerjaan kepala rumah tangga. Hal ini bisa terjadi karena permintaan tenaga kerja yang terbatas dengan karakteristik perekonomian di Jakarta yang didominasi oleh sektorsektor padat modal dan tehnologi atau adanya ketidaksesuaian kualifikasi angkatan kerja dengan lapangan kerja yang sebenarnya dapat disediakan dan pemerintah daerah dalam hal ini masih kurang optimal dalam mendorong terciptanya kegiatan ekonomi di sektorsektor yang banyak meyerap tenaga kerja.

\section{Indeks Kedalaman Kemiskinan (P1) dan Indeks Keparahan Kemiskinan (P2)}

Indeks kedalaman kemiskinan (Poverty Gap Index) adalah ukuran kemiskinan yang menghitung seberapa jauh individu jatuh dibawah kemiskinan (jika termsuk kategori miskin). Indeks kedalaman ini merupakan ukuran rata-rata kesenjangan pengeluaran masing-masing penduduk miskin terhadap garis kemiskinan. Selanjutnya Indeks keparahan kemiskinan (Poverty Severity Indeks) adalah distribusi penyebaran pengeluaran diantara penduduk miskin. Untuk melihat gambaran Indeks kedalaman kemiskinan dan Indeks keparahan kemiskinan di Jakarta Timur dapat dilihat pada Gambar 2.

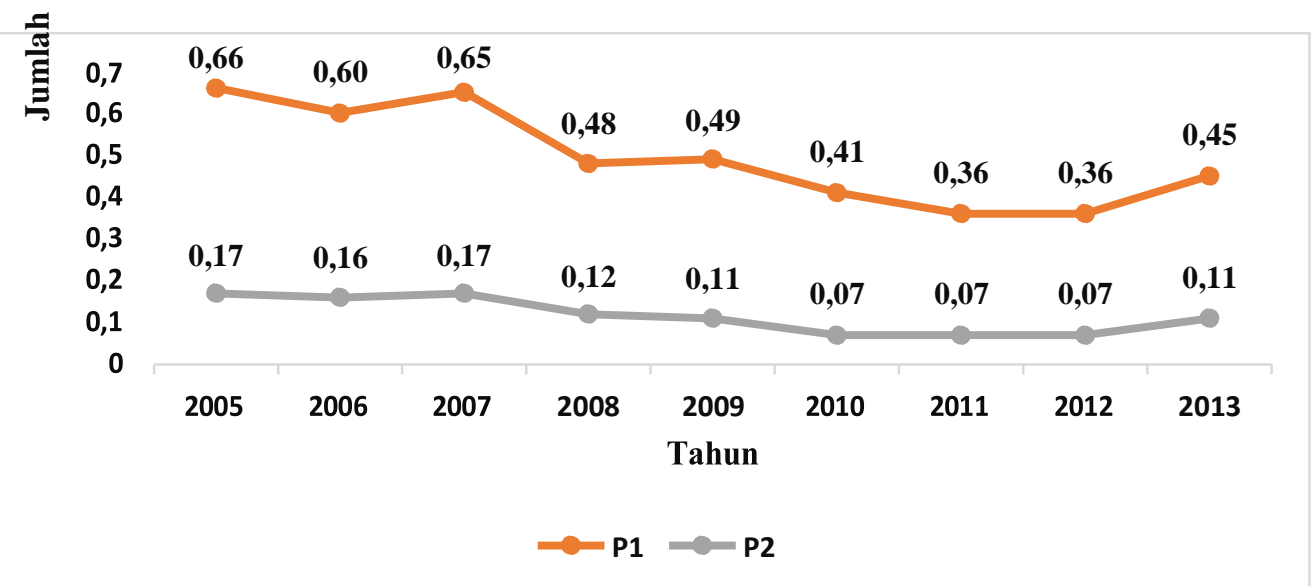

Gambar 2 Tingkat kedalaman dan keparahan kemiskinan di Kota Jakarta Timur antara tahun 2005-2013

Indeks kedalaman kemiskinan (P1) di Jakarta Timur pada tahun 2005 sampai tahun 2010 mengalami penurunan dari 0,66 menjadi 0,41 , yang berarti penduduk miskin di Jakarta Timur yang mempunyai pendapatan rendah telah berkurang sehingga jurang kemiskinan semakin kecil, selanjutnya Indeks Keparahan Kemiskinan (P2) dari tahun 2005 sampai tahun 2010 juga mengalami penurunan dari 0,17 menjadi 0,07 yang berarti penduduk miskin yang mempunyai pendapatan rendah semakin mengelompok, sehingga dalam penanganan pengentasan kemiskinan di Jakarta Timur relatif semakin mudah. Namun pada tahun 2013 terjadi kondisi yang kurang baik karena adanya kenaikan 
baik pada tingkat kedalaman kemiskinan maupun pada tingkat keparahan kemiskinan.

\section{Perubahan Garis Kemiskinan}

Garis kemiskinan adalah batas minimal pengeluaran konsumsi dari penduduk untuk memenuhi kebutuhan pangan dan non pangan yang bersifat mendasar (pangan, sandang, perumahan, kesehatan, dan pendidikan). Garis Kemiskinan dapat diartikan sebagai garis pembatas yang membedakan tingkat kesejahteraan. Garis kemiskinan akan berubah antar waktu yang disebabkan perubahan harga (inflasi). Untuk melihat perkembangan garis kemiskinan di Jakarta Timur dapat dilihat pada Gambar 3.

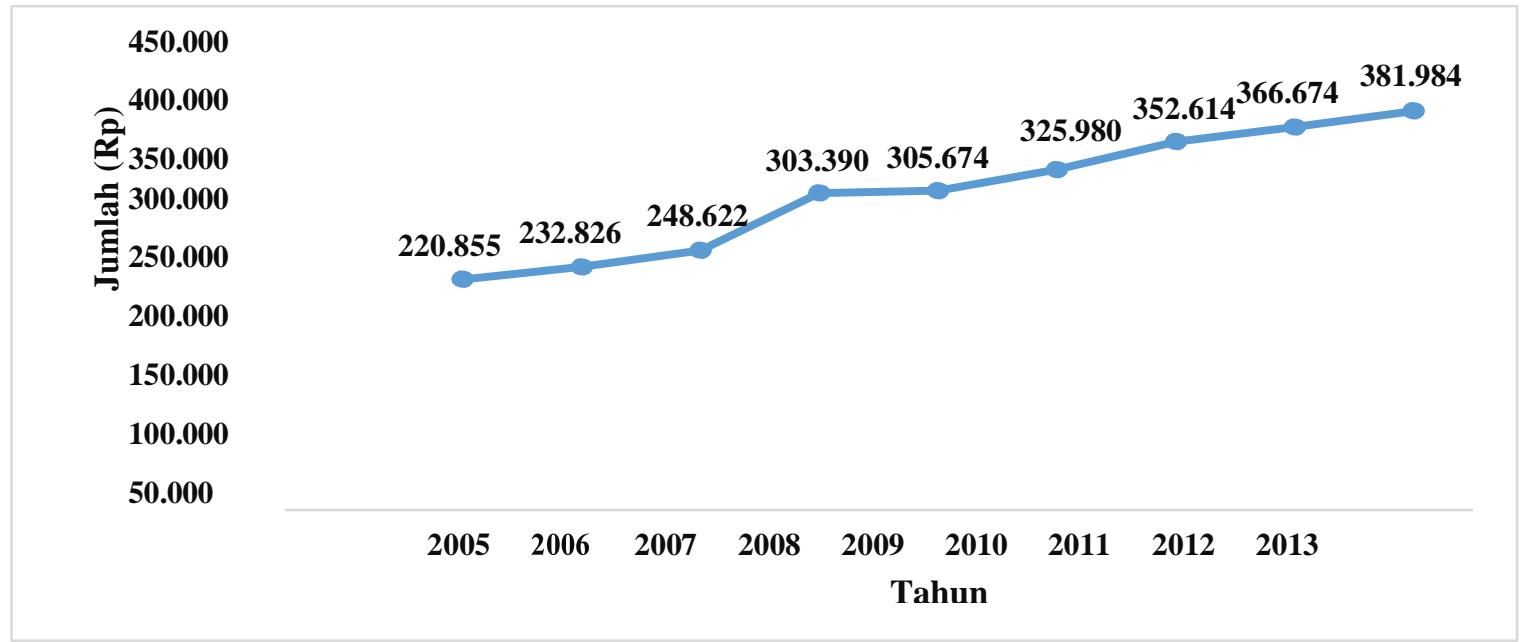

Gambar 3 Perubahan garis kemiskinan di Kota Jakarta Timur

Berdasarkan Gambar 3 dapat disimpulkan bahwa pada kurun waktu antara tahun 2005 - 2013 telah terjadi perubahan (kenaikan garis) kemiskinan sebesar Rp.161.129,- atau terjadi rata-rata inflasi sebesar 9 persen/tahun.

\section{Faktor-faktor yang Mempengaruhi Terjadinya Kemiskinan Rumah Tangga}

Berdasarkan hasil Uji Hosmer and Lemeshow diketahui, bahwa nilai chi square tabel untuk DF 8 (jumlah variabel independen -1) pada taraf nyata 0,05 adalah sebesar 14,067. Karena nilai chi square Hosmer and Lemeshow hitung 2,481 < chi square tabel 14,067 dan nilai signifikansi $0,963(>0,05)$ artinya model menerima Ho. Keputusan menerima Ho menunjukan bahwa tidak ada perbedaan yang nyata antara klasifikasi yang diprediksi dengan klasifikasi yang diamati atau model diterima karena 26 model mampu memprediksi nilai observasinya.
Dari hasil regresi diketahui bahwa selisih nilai -2 Log likelihood sebelum variabel independen masuk model: 150,785 dikurangi -2 Log likelihood setelah masuk model 107,976 adalah nilai chi square 42,809. Jadi karena nilai chi square hitung 42,809> chi square tabel pada DF 8 (jumlah variabel independen) yaitu 15,507 atau dengan signifikansi sebesar $0,000 \quad(<0,05)$, maka jawaban terhadap hipotesis pengaruh simultan variabel independen terhadap variabel dependen adalah menerima $\mathrm{H}_{1}$ dan menolak $\mathrm{Ho}_{\mathrm{o}}$ atau berarti ada pengaruh signifikan secara simultan variabel jenis kelamin, umur, besaran anggota rumah tangga, proporsi anggota rumah tangga yang bekerja, status/jenis pekerjaan kepala keluarga dan pendidikan kepala keluarga terhadap kejadian kemiskinan rumah tangga karena nilai $p$ value chi square sebesar 0,000 dimana <alpha 0,05 atau nilai chi square hitung 42,809> chi square tabel 15,507. 
Pengujian koefisien determinasi pada regresi logistik menggunakan Nagelkerke $R$ Square atau Pseudo $R$ Squre. Tujuan dari pengujian ini adalah untuk mengetahui seberapa besar kombinasi variabel independen yaitu jenis kelamin, umur, besaran anggota rumah tangga, proporsi anggota rumah tangga yang bekerja, status/jenis pekerjaan kepala keluarga dan pendidikan kepala keluarga mampu menjelaskan variasi variabel dependen yaitu peluang terjadinya rumah tangga miskin. Pada hasil output regresi didapatkan nilai Nagelkerke $R$ Square 0,307. Ini mengindikasikan variabel independen hanya mampu menjelaskan variabel dependen sebesar 30 persen. Atau hanya 30 persen dari variasi variabel dependen (kejadian kemiskinan) yang dapat dijelaskan oleh model.
Menurut Gujarati (2003) dalam Hakim (2007) berpendapat bahwa kecilnya Pseudo $R$ Square belum tentu merepresentasikan jeleknya model dalam regresi logistik, karena hal penting yang harus diamati adalah indikator signifikansi model, signifikansi variabelvariabel independen, dan arah koefisien dari variabel-variabel tersebut. Sedangkan besaran Pseudo $R$ square tidak diutamakan. Selanjutnya agar mengetahui lebih jelas kemampuan prediksi model digunakan nilai tabel klasifikasi.

Berdasarkan hasil Analisis Regresi Logistik (Juanda, 2009) dari delapan variabel independen yang diamati, terdapat tiga variabel yang berpengaruh terhadap peluang terjadinya rumah tangga miskin yaitu jenis kelamin (gender), besaran anggota rumah tangga, dan proporsi anggota rumah tangga yang bekerja (Tabel 1).

Tabel 1 Hasil Analisis Regresi Logistik antara keadaan rumah tangga miskin dan rentan miskin dengan peubah sosial ekonomi

\begin{tabular}{lccccc}
\hline $\begin{array}{l}\text { Peubah prediktor } \\
(\mathrm{X})\end{array}$ & $\begin{array}{c}\text { Estimasi } \\
\text { parameter } \beta\end{array}$ & $\begin{array}{c}\text { Standar } \\
\text { kesalahan }\end{array}$ & $\begin{array}{c}\text { Statistik } \\
\text { Wald }\end{array}$ & p- value & Odd Rasio \\
\hline JK* & 1,603 & 0,682 & 5,518 & 0,019 & 4,966 \\
Umur & 0,020 & 0,024 & 0,698 & 0,404 & 1,020 \\
ART* & 0,811 & 0,178 & 20,686 & 0,000 & 2,249 \\
ARTKer* $_{\text {D_Stat }}$ & $-1,380$ & 0,494 & 7,793 & 0,005 & 0,252 \\
D_Stat $_{2}$ & 18,898 & 7785,327 & 0,000 & 0,998 & $1,612 \mathrm{E} 8$ \\
D_Pend $_{1}$ & 0,484 & 0,585 & 0,685 & 0,408 & 1,623 \\
D_Pend $_{2}$ & $-0,809$ & 0,677 & 1,426 & 0,232 & 0,445 \\
Constant $^{\text {Ponstand }}$ & $-0,207$ & 0,803 & 0,066 & 0,797 & 0,813 \\
\hline
\end{tabular}

Pseudo R Square : $0,307, G^{2}=42,809>\chi^{2}(\mathbf{0}, 05 ; 8)$

Sumber : BPS Susenas KOR, 2013 (diolah) Keterangan : *) signifikan pada taraf nyata 5\%

Hasil Analisis Regesi Logistik pada taraf nyata $5 \%$ perempuan yang menjadi kepala keluarga mempunyai pengaruh positif dan signifikan terhadap peluang terjadinya rumah tangga miskin. Dengan odds ratio dari peubah gender (JK) sebesar 4,966 berarti perempuan yang menjadi kepala keluarga mempunyai peluang terjadinya rumah tangga miskin 5 kali lebih besar daripada laki-laki.Hasil penelitian ini hampir sama dengan penelitian Adianti (2005) di Provinsi DKI pada taraf nyata 1
$\%$ dan odds ratio 2,386.

Berdasarkan penelitian-penelitian terdahulu disimpulkan bahwa besaran rumah tanggam mempunyai hubungan yang positif terhadap peluang terjadinya rumah tangga miskin. Penelitian tersebut yaitu Adianti (2005) di DKI Jakarta dan Nurdyana (2012) di Maluku Utara. Hasil Analisis Regresi Logistik terhadap populasi rumah tangga di Kota Jakarta Timur pada taraf nyata $1 \%$ menunjukan bahwa besaran anggota 
rumah tangga berpengaruh signifikan dan positif terhadap peluang terjadinya rumah tangga miskin. Dengan nilai odds rasio sebesar 2,249 berarti setiap ada penambahan satu orang anggota rumah tangga, maka peluang rumah tangga menjadi miskin bertambah sebesar 2,25 kali.

Hal ini sesuai dengan penelitian Adianti (2005) di Provinsi DKI dengan odds ratio 1,694. Proporsi anggota rumah tangga yang bekerja akan mempengaruhi tingkat pendapatan keluarga, yang pada akhirnya berpengaruh terhadap kemiskinan. Hasil Analisis Regresi Logistik pada penelitian ini menunjukan bahwa pada taraf nyata $1 \%$, anggota rumah tangga yang bekerja, berpengaruh signifikan dan negatif terhadap peluang terjadinya rumah tangga miskin. Dengan odds rasio sebesar 0,252 berarti dengan penambahan satu orang anggota rumah tangga yang bekerja peluang terjadinya rumah tangga miskin akan berkurang 0,252 kali. Sama halnya dengan penelitian Adianti (2005) di Provinsi DKI dimana dengan penambahan satu orang anggota rumah tangga yang bekerja akan menurunkan peluang terjadinya rumah tangga miskin sebesar 0,49 kali.

\section{SIMPULAN}

Berdasarkan hasil dan pembahasan yang telah disajikan, dapat disimpulkan bahwa faktor-faktor yang mempengaruhi terjadinya kemiskinan rumah tangga di Kota Jakarta Timur adalah gender, besaran anggota rumah tangga dan proporsi anggota rumah tangga yang bekerja.

\section{SARAN}

Tersedianya data laporan kinerja penanggulangan kemiskinan pertahun agar dari data tersebut dapat diregresikan untuk mengetahui tingkat efektivitas program/kegiatan terhadap output maupun outcome. Saran untuk penelitian selanjutnya adalah penggunaan Basis Data Terpadu tahun 2015 dari Tim Nasional Percepatan Penanggulangan Kemiskinan (TNP2K) sebagai bahan analisis data yang pada pertengahan masa penelitian ini baru dikeluarkan publikasinya.

\section{DAFTAR PUSTAKA}

Adianti G. 2005. Analisis faktor-faktor yang mempengaruhi kemiskinan di DKI Jakarta (Study komparatif di permukiman kumuh dan tidak kumuh) [tesis] Bogor (ID): Institut Pertanian Bogor.

Aryanti D. 2011. Analisis kemiskinan pada penduduk Betawi vis-a-vis pendatang di DKI Jakarta [tesis] Bogor (ID): Institut Pertanian Bogor.

[Bappenas] Badan Perencanaan Pembangunan Nasional. 2015. Seri Analisis Pembangunan Wilayah Pemerintah Provinsi DKI Jakarta. Jakarta (ID): Bappenas.

[BPS] Badan Pusat Statistik. 2009. Analisis Kemiskinan, Ketenagakerjaan dan Distribusi Pendapatan. Jakarta (ID): Nario Sari.

[BPS Kota Jakarta Timur] Badan Pusat Statistik. 2015. Jakarta Timur dalam Angka. Jakarta (ID): BPS.

[BPS Kota Jakarta Timur] Badan Pusat Statistik. 2015. Statistik Daerah Kota Jakarta Timur. Jakarta (ID): BPS.

Gujarati D. 2003. Ekonometrika Dasar. Jakarta (ID): Erlangga.

Hakim RA. 2007. Analisis determinan tingkat kejahatan properti di Jawa tahun 2007 [skripsi] Jakarta (ID): Universitas Indonesia.

Juanda B. 2009. Ekonometrika: Permodelan dan Pendugaan. Bogor (ID): IPB Press. Kasim M. 2006. Karakteristik Kemiskinan di Indonesia \& Strategi Penanggulangannya. Jakarta (ID): Indomedia Global.

Nurdyana H. 2012. Pendidikan dan kemiskinan: studi kasus Provinsi Maluku Utara [tesis] Bandung (ID): Universitas Padjadjaran.

Tambunan T. 2016. Pembangunan 
Ekonomi Inklusif. Jakarta (ID): LP3ES.

Tasrif MA, Sulistyadi W, Budiarti, Afifah EN. 2008. Apakah Pembangunan di DKI Jakarta Memihak Rakyat Miskin? Jakarta (ID): Kemitraan. 